\title{
ANALISIS KEBIJAKAN LUAR NEGERI AMERIKA SERIKAT ERA JOE BIDEN TERHADAP PROGRAM PENGEMBANGAN NUKLIR IRAN
}

\author{
ANALYSIS OF FOREIGN POLICY OF THE UNITED STATES OF THE JOE BIDEN ERA ON \\ PROGRAM DEVELOPMENT NUCLEAR IRAN \\ Resqita Trisya Nurtyandini \\ Program Studi Hubungan Internasional, Universitas Singaperbangsa Karawang \\ Email: 2010631260041@ student.unsika.ac.id
}

\begin{abstract}
ABSTRAK
Ambisi Iran untuk mengembangkan senjata nuklirnya telah memunculkan kekhawatiran banyak negara di dunia. Salah satunya Amerika Serikat, yang menganggap program pengembangan nuklir Iran dapat mengganggu sistem perimbangan kekuatan di Timur Tengah, serta dapat menghalangi Amerika Serikat dalam menebar hegemoninya di kawasan tersebut. Artikel ini bertujuan untuk menganalisis kebijakan luar negeri Amerika Serikat terhadap program pengembangan nuklir Iran pada masa presiden Joe Biden, meningat Donald Trump pada masa kepemimpinannya terus menggelorakan perlawanan. Penelitian ini menggunakan pendekatan kualitatif dengan dengan mengkaji literatur dari berbagai sumber data sekunder. Adapun teori yang digunakan ialah perspektif konstruktivisme, kebijakan luar negeri serta teori rational choice. Hasil penelitian menunjukkan bahwa, berbeda dengan Trump yang menerapkan “tekanan maksimum' khususnya dalam bidang ekonomi untuk menghadapi nuklir Iran, Joe Biden lebih mengutamakan pendekatan diplomatik sebagai mekanisme resolusi konflik. Sanksi ekonomi atau tekanan secara diplomatik akan tetap berlaku, tetapi pada saat yang sama akan meringankan sanksinya dan meningkatkan hubungannya dengan Iran.

Kata Kunci : Amerika Serikat, Kebijakan Luar Negeri, Joe Biden, Nuklir, Iran

\section{ABSTRACT}

Iran's ambition to develop its nuclear weapons has raised concerns in many countries around the world, including the United States, which considers that Iran's nuclear development could threaten the Balance of Power system in the Middle East and could prevent the United States from expanding its hegemony in the region. This article aims to analyze the U.S. foreign policy during the Joe Biden era towards Iran's nuclear development program, considering Donald Trump, during his leadership continues to stir up resistance. This research uses a qualitative approach by reviewing literature from various secondary data sources. The theories used are constructivism perspectives, foreign policy and rational choice theory. The results showed that, in contrast to Trump who applied "maximum pressure" especially in the economic field to deal with nuclear Iran, Joe Biden prioritized a diplomatic approach as a conflict resolution mechanism. Economic sanctions or diplomatic pressure will remain in place, but at the same time will ease its sanctions and improve its relations with Iran.
\end{abstract}

Keywords : The United States, Foreign Policy, Joe Biden, Nuclear, Iran 


\section{PENDAHULUAN}

Berakhirnya Perang Dingin yang terjadi antara Blok Barat dan Blok Timur pada tahun 1991, telah mendorong banyak negara untuk mengembangkan persenjataan dan kekuatan militernya (arms of race) terutama pengembangan kemampuan teknologi nuklir. Hal tersebut dilatarbelakangi oleh berbagai alasan, mulai dari alasan keamanan dimana kepemilikan senjata nuklir dianggap sebagai upaya suatu negara untuk mencegah ancaman militer dan tindakan ofensif dari negara lain (deterrence) hingga alasan untuk meningkatkan serta memperkuat pengaruh negaranya dalam percaturan politik global (Jemadu, 2008).

Pengembangan senjata militer pemusnah massal yang memanfaatkan energi nuklir ini telah menginspirasi upaya terus-menerus untuk mengendalikannya (Hunt, 2017). Salah satu negara yang melakukan program pengembangan teknologi nuklir yaitu Iran, sebagai salah satu alternatif untuk menangani krisis sumber daya energi domestiknya. Ketertarikan Iran untuk mengembangkan teknologi nuklir sudah berlangsung sejak tahun 1953 pada masa kepemimpinan Shah Muhammad Reza Pahlevi. Sejak saat itulah Iran mendapat dorongan penuh Amerika Serikat melalui sebuah perjanjian bilateral kerja sama nuklir dan bantuan teknis berupa suplai bahan baku reaktor nuklir berkekuatan lima megawatt bersama dengan uranium yang diperkaya untuk bahan bakar sesuai program The US Atom for Peace (Krige, 2006). Dengan bantuan tersebut, pada tahun 1959 Shah mendirikan sebuah Pusat Penelitian Nuklir Teheran yang kemudian dijalankan oleh Atomic Energy Organization of Iran (AEOI) (Kartini, 2005).

Namun setelah Revolusi Islam Iran tahun 1979 terjadi yang ditandai dengan bergulingnya kekuasaan Muhammad Reza Pahlevi dari kursi pemerintahan dan digantikan oleh Ayatullah Ruhollah Khomenei, membuat hubungan diplomatik Iran dengan berbagai negara kian meregang, termasuk Amerika Serikat yang menarik kembali dukungannya terhadap program nuklir Iran. Hal tersebut dikarenakan Khomenei yang dianggap anti-barat akan menghalangi kepentingan Amerika Serikat di kawasan Timur Tengah dalam menebar hegemoninya (Kibaroglu, 2006).

Ambisi pengembangan nuklir Iran yang kembali memuncak pada awal tahun 2000 setelah sempat terhenti selama masa kepemimpinan Khomenei, menghadapkan Iran pada 
tuduhan bahwa program pengembangan senjata nuklirnya untuk tujuan militer, yang mana hal tersebut melanggar komitmennya dalam Perjanjian Non-Proliferasi Nuklir (NPT) yang ditandatangi Iran pada 1 Juli 1968 dan diratifikasi 5 Maret 1970 (Khan, 2010). Meskipun Iran menyatakan secara tegas tujuannya murni untuk perdamaian, namun hal tersebut tetap menuai pro dan kontra dari beberapa negara.

Amerika Serikat yang pada awalnya mendorong pengembangan nuklir Iran, kini terbukti sangat menentang eksistensi senjata nuklir tersebut. Bagi Amerika Serikat, jika program nuklir Iran sudah berada pada level senjata maka akan mengancam sistem Balance of Power atau perimbangan kekuatan di Timur Tengah, hal tersebut menjadikan Iran sebagai isu kontroversial dan fokus utama kebijakan luar negeri Amerika Serikat di Timur Tengah bersamaan dengan Israel (Ramadhan, 2019). Berbagai upaya terus dilakukan pemerintah Amerika Serikat yang tercermin dalam kebijakan luar negerinya untuk menuntaskan masalah ancaman nuklir Iran tersebut, misalnya pembentukan Join Comprehensive Plan of Action (JCPOA) serta penerapan sanksi ekonomi oleh Amerika Serikat kepada Iran (Sundari, 2020).

\subsection{Rumusan Masalah}

Setelah terpilihnya Joe Biden sebagai presiden Amerika Serikat, dinamika hubungan Amerika Serikat dengan Iran khususnya dalam hal pengembangan senjata nuklir sampai saat ini belum menemui titik terang apalagi pada masa presiden Donald Trump, Amerika Serikat terus menggelorakan perlawanannya. Berdasarkan kondisi tersebut, memunculkan perumusan masalah untuk penelitian ini yaitu "Bagaimana kebijakan luar negeri Amerika Serikat pada era Joe Biden terhadap program pengembangan nuklir Iran?"

\section{TINJAUAN LITERATUR}

Sebelum merujuk pada pembahasan yang lebih rinci, penting untuk memahami beberapa penelitian sebelumnya yang mengkaji dinamika hubungan antara Amerika Serikat dan Iran dalam kaitannya dengan pengembangan senjata nuklir. Hal ini bertujuan untuk memperbaharui penelitian-penelitian sebelumnya. Kajian yang mengelabrosi dinamika hubungan Amerika Serikat dengan Iran telah cukup banyak dieksplorasi dan diperdebatkan. Namun, dari sejumlah kajian yang ada, belum ada kajian yang melihat kebijakan luar negeri Amerika Serikat pada 
masa presiden Joe Biden dalam kaitannya dengan program pengembangan nuklir Iran secara lebih rinci. Oleh karena itu, penulis menganggap pentingnya sebuah kajian yang dapat menganalisis permasalahan tersebut dengan lebih terperinci. Penulis menggunakan tiga buah literatur terdahulu yang dijadikan sebagai referensi dalam penelitian kali ini.

Pertama, sebuah jurnal yang berjudul 'Strategi Amerika Serikat Dalam Menekan Pengembangan Nuklir Iran', karya Rio Sundari (2020) dan terpublikasi pada jurnal Frequency of International Relations. Hasil penelitiannya menunjukkan berbagai cara dan strategi yang dilakukan Amerika Serikat untuk menghentikan program nuklir Iran, diantaranya dengan menjatuhkan sanksi ekonomi kepada Iran yang membuat meningkatnya inflasi dan angka pengangguran di Iran. Selain itu dengan jalan diplomasi, Amerika Serikat meminta negaranegara lain terutama negara Eropa untuk turut memberikan sanksi ekonomi kepada Iran yang mana memperparah kondisi perekonomian Iran. Strategi terakhir yang digunakan Amerika Serikat yaitu dengan menjatuhan sanksi terhadap Iran melalui PBB. Dikarenakan Amerika Serikat adalah salah satu penyumbang dana terbesar untuk PBB, membuat Amerika Serikat berada dalam posisi strategis untuk dapat mengontrol kebijakan di PBB.

Kedua, MF Abdillah (2019) dalam tulisannya yang berjudul ' Kebijakan Amerika Serikat Terhadap Iran Pasca Mundurnya Amerika Serikat dari Joint Comprehensive Plan of Action (JCPOA), dan terpublikasi pada jurnal Universitas Komputer Indonesia, menggambarkan kebijakan sanksi ekonomi yang mendominasi kebijakan Amerika Serikat kepada Iran pasca kemundurannya di JCPOA disebabkan karena ketidakefektifan perjanjian tersebut serta pelanggaran yang dilakukan Iran terhadap ketentuan JCPOA. Pasca kemundurannya dari JCPOA, Amerika Serikat terus menuntut Iran untuk mengakhiri ambisi nuklirnya. Selain itu, Amerika Serikat menggunakan instrumen koersif atau ancaman dalam kebijakan luar negerinya terhadap Iran, salah satunya dengan terus menekan sanksi ekonomi sampai Iran mau mengikuti apa yang diperintah dan diinginkan oleh Amerika Serikat.

Penelitian ketiga yaitu berjudul 'Kepemilikan Nuklir dan Keamanan Nasional Iran: Suatu Studi Kasus', karya Obsatar Sinaga (2009) dan terpublikasi pada jurnal Sosiohumaniora: Journal of Social Sciences and Humanities, hasil penelitiannya menunjukkan bahwa semua tekanan dari dunia internasional yang ditujukan kepada Iran tidak mengubah sikap negara ini untuk terus memajukan pengembangan nuklirnya. Hal ini disebabkan kehawatiran Iran akan 
kemungkinan serangan dari Amerika Serikat, karena pernyataan Amerika Serikat yang sering bertentangan dan kebijakan luar negerinya. Dengan kata lain, program nuklir Iran tidak hanya ditujukan untuk meningkatkan efisiensi penggunaan sumber daya energi negaranya saja, tetapi juga untuk meningkatkan keamanan nasional Iran dari ancaman hegemoni Amerika Serikat di Timur Tengah.

\section{KERANGKA TEORETIS}

\subsection{Perspektif Konstruktivisme}

Konstruktivisme merupakan pendekatan dalam studi hubungan internasional yang memandang fenomena internasional tidak hanya bertumpu pada pencapaian kepentingan semata, tetapi juga dipengaruhi unsur-unsur lain seperti identitas (identity), intensi (intention), bahasa (language) dan nilai-nilai (value). Unsur-unsur tersebut menjadi faktor penentu apakah suatu negara dapat menjadi "kawan" atau 'lawan" bagi negara lain (Onuf, 1989). Peran paradigma dalam proses pembuatan kebijakan sangat krusial terhadap pembentukan persepsi yang menentukan formulasi politik luar negeri suatu negara. Konstruktivisme melihat realitas internasional sebagai hasil konstruksi sosial para pembuat kebijakan.

Dalam kasus ancaman program nuklir Iran, konstruktivisme menjelaskan bahwa yang menjadi masalah atas realitas senjata nuklir bukanlah kemampuan destruktifnya, melainkan pemberian makna kemampuan senjata tersebut oleh konteks sosial (Azwar \& Suryana, 2013). Selain itu, keberatan Amerika Serikat terhadap program nuklir Iran terjadi karena kurangnya interaksi simbolik antar-subjek dan afinitas identitas, sehingga Amerika Serikat cenderung menganggap Iran sebagai 'lawan"' (Hadiwinata, 2017).

\subsection{Kebijakan Luar Negeri}

Kebijakan luar negeri adalah suatu program atau agenda yang dibuat oleh pembuat kebijakan politik di suatu negara terhadap negara lain dalam mencapai kepentingan nasionalnya (Morin \& Paquin, 2018). Negara menjadi aktor utama yang bertanggung jawab terhadap kebijakan luar negeri. Pembentukan kebijakan luar negeri mencakup proses perencanaan, strategi terhadap tujuan yang dimaksud, serta implementasinya. Tujuan dalam kebijakan luar 
negeri merupakan program yang ingin tercapai di masa depan dengan tetap mempertimbangkan kapabilitas yang dimiliki oleh negaranya (Rosenau, 1969).

\subsection{Teori Rational Choice}

Penulis menggunakan teori pilihan rasional (rational choice theory) untuk menjelaskan kebijakan luar negeri Amerika Serikat yang dipengaruhi berbagai faktor rasional. Teori pilihan rasional menganalisis hubungan timbal balik antara keinginan (desire), informasi (information), dan kepercayaan (beliefs) tindakan aktor rasional sebagai reaksi terhadap pihak atau negara lain. Sederhananya, ketika seseorang menghadapi banyaks tindakan atau rencana, aktor tersebut akan cenderung mengambil opsi yang paling menguntungkan berdasarkan perhitungan rasionalnya (Elster, 1989).

Teori pilihan rasional (rational choice tehory) juga diistilahkan sebagai model rasional. Model rasional menggambarkan hubungan kebijakan politik luar negeri berbagai negara bagaikan aksi dan reaksinya terhadap negara lain sehingga membuat model tersebut dominan dalam analisis kebijakan luar negeri. Model rasional mengasumsikan bahwa negara merupakan aktor yang berusaha memaksimalkan kepentingan serta tujuannya berdasarkan perhitungan rasional di kancah politik internasional (Perwita \& Yani, 2017).

\section{METODOLOGI PENELITIAN}

Metode penelitian merupakan suatu upaya, cara, prinsip, dan prosedur yang digunakan untuk mencari jawaban atas suatu permasalahan (Bogdan \& Taylor, 1975). Penelitian ini menggunakan pendekatan kualitatif dengan mengkaji hubungan kausal (hubungan sebab akibat) antara tindakan dan konsekuensi serta analisis deskriptif. Pengumpulan data dilakukan dengan studi kepustakaan (library reasearch) berbagai sumber data sekunder seperti buku-buku, artikel ilmiah, situs lembaga resmi pemerintah, situs berita online dan beberapa jurnal yang diperoleh dari berbagai literatur terkait topik penelitian (Mardalis, 2006). Semua data yang telah terkumpul secara sistematis, selanjutnya difilterisasi dan ditarik kesimpulan umum sehingga menghasilkan data yang akurat dan disajikan secara deskriptif analitis. Data sekunder mendominasi penelitian, namun tetap mampu mengakomodir kebutuhan penelitian. 


\section{HASIL DAN PEMBAHASAN}

Dalam menganalisis kebijakan luar negeri Amerika Serikat, penting untuk memahami keterlibatan berbagai pihak dalam proses pengambilan keputusan. Proses pembentukan kebijakan luar negeri suatu negara tidak dilakukan oleh negara secara keseluruhan, melainkan dengan partisipasi berbagai aktor independen. Dengan kata lain, masing-masing pihak tersebut memiliki pendapatnya sendiri tentang kebijakan luar negeri yang sesuai dengan kepentingan sektor dan individu serta kebijakan luar negeri yang bergantung pada interaksi antara orangorang yang terlibat (Freedman, 1976). Salah satunya, selama masa kampanye Joe Biden, Antony Blinken yang menjadi penasihat kebijakan luar negeri Amerika Serikat menganut prinsip internasionalisme liberal yang sama dengan Joe Biden tetapi sedikit lebih agresif. Mendukung mobilisasi kekuasaan atas nama kemanusiaan, hak asasi manusia, demokrasi, dan hukum internasional telah menjadi fokus pemikiran politik luar negerinya. Dalam satu dekade kedepan dibawah arahan Biden, Blinken akan membentuk visi bersama antara keduanya mengenai konsep kebijakan luar negeri Amerika Serikat (Sulaeman \& Tiara, 2021).

Kembalinya Joe Biden ke Gedung Putih memunculkan berbagai spekulasi perihal keberlanjutan kebijakan luar negeri Amerika Serikat, antara lain; restorasi, reformasi, dan revolusi (Han \& Jeong, 2020). Oleh karena itu, kebijakan luar negeri Biden perlu ditinjau ulang untuk mengantisipasi kebijakan yang mungkin diambil Biden di masa depan. Namun dengan rekam jejak yang meyakinkan bahkan dianggap sebagai produk terbaik dalam pembentukan kebijakan luar negeri Amerika Serikat, Biden dianggap telah menunjukkan integritasnya (Nainggolan \& Muhamad, 2020).

Dalam kepemimpinannya kali ini, Biden mengutamakan pendekatan diplomatik sebagai mekanisme resolusi konflik. Hal ini tercermin dalam landasan utama kebijakan luar negeri Biden, yaitu multilateralisme. Dalam pidato kemenangannya, Biden menekankan bahwa Amerika Serikat akan menjadi mercusuar yang memimpin negara-negara berdaulat dalam menghadapi ancaman internasional (the world's beacon) (Sulaeman \& Tiara, 2021). Upaya Biden untuk meningkatkan citra Amerika Serikat di mata dunia yaitu dengan kembali menjadi bagian dari kerja sama multilateral global yang ditinggalkan Trump selama pemerintahannya.

Menurut laporan BBC (2020), Joe Biden menyatakan bahwa hubungan bilateral dan multilateral Amerika Serikat dalam sistem internasional telah "rusak", oleh karenanya Biden 
berjanji akan memperbaikinya sesegera mungkin. Mengenai masalah dengan Iran, Biden mengatakan bahwa Amerika Serikat siap untuk bergabung kembali kedalam Joint Comprehensive Plan of Action (JCPoA). Tetapi, setelah Trump menarik diri di tahun 2018 dari perjanjian JCPoA, Biden akan menghadapi banyak tantangan ketika memutuskan untuk kembali bergabung dengan JCPoA. Serangkaian sanksi AS yang kompleks yang telah dijatuhkan Trump selama dua tahun terakhir akan memiliki banyak dampak potensial pada Biden.

Sejauh ini, Biden mengatakan dalam kutipan BBC pada bulan Januari (2020) bahwa pemberian sanksi ekonomi kepada Iran akan terus berlanjut sampai Iran kembali ke kesepakatan dan memenuhi janji serta komitmennya pada JCPoA. Namun tersebut bisa sulit untuk dilakukan karena Iran telah gagal memenuhi komitmennya untuk membatasi program pengembangan nuklirnya sesuai dengan perjanjian tahun 2015 tersebut.

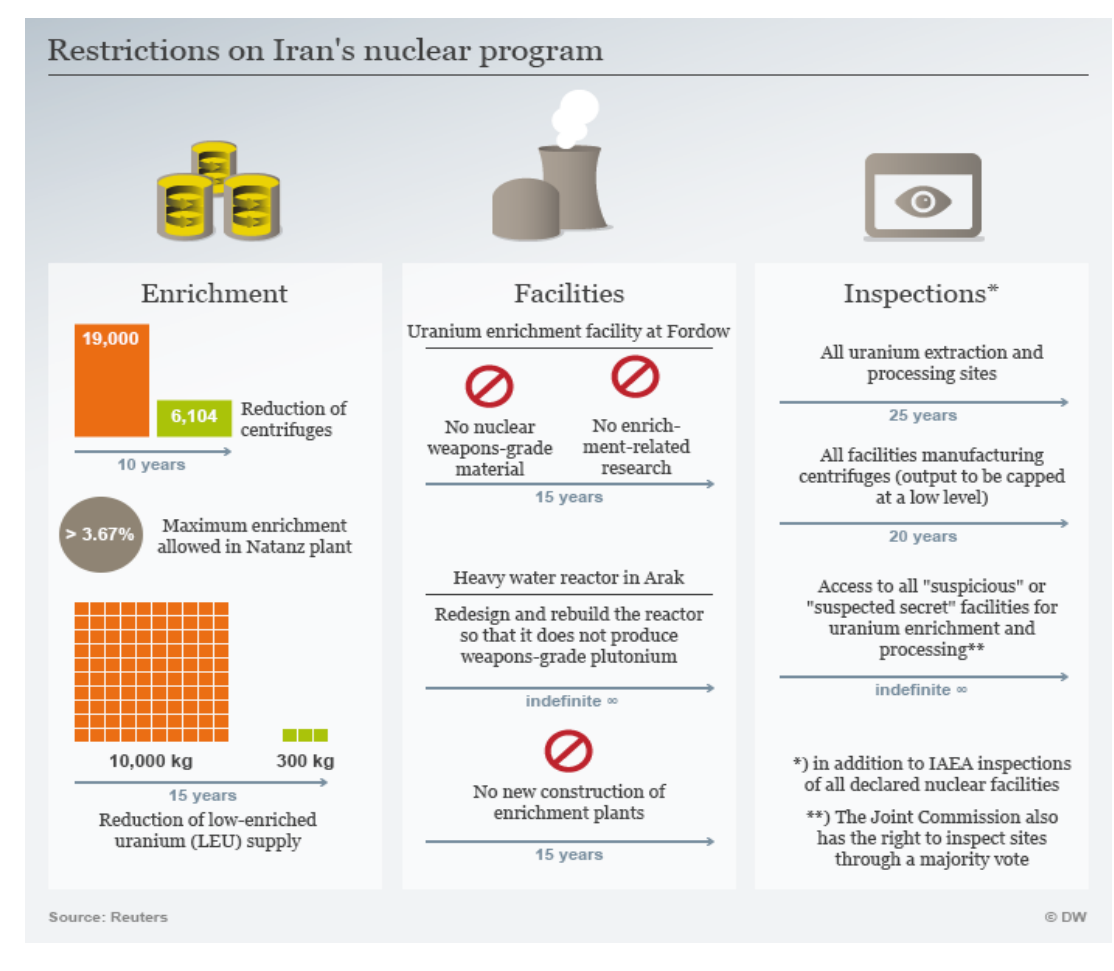

Gambar 1. Pembatasan program nuklir Iran

(Sumber: www.dw.com)

Menurut laporan triwulanan International Atomic Energy Agency (IAEA), Iran menyimpan lebih banyak uranium dan telah memulai pengayaan uranium dengan kemurnian mencapai 3,67\% melebihi batas kesepakatan JCPoA. Elliott Abrams, utusan AS untuk Iran, 
mengatakan bahwa sanksi atas pelanggaran tersebut akan terus berlanjut. Serta pengawasan oleh PBB terhadap program nuklir Iran juga akan terus berlanjut (BBC, 2019).

\subsection{Perubahan dan kontinuitas kebijakan Amerika Serikat dari era Donald Trump sampai era Joe Biden}

Banyak perubahan dan kontinuitas yang terjadi pada kebijakan luar negeri Amerika Serikat di setiap periodenya. Perubahan signifikan terjadi saat Donald Trump mengeluarkan diri dari kesepakatan Joint Comprehensive Plan of Action (JCPoA) secara sepihak serta menerapkan 'tekanan maksimum', khususnya dalam bidang ekonomi untuk melumpuhkan Iran dalam memajukan kemampuan nuklirnya.

Dalam beberapa kasus yang telah terjadi, para pengambil keputusan memiliki kemampuan terbatas untuk merumuskan kebijakan berdasarkan model rasional. Misalnya ketika Donald Trump memutuskan untuk mengundurkan diri dari JCPoA. Fokus sisi kognitif Trump terletak pada gambaran (images) dan keyakinannya (beliefs) tentang kesepakatan nuklir tersebut. Konsistensi afektif-kognitif berarti bahwa pembuat kebijakan cenderung terlalu memperhatikan apa yang mereka yakini dan mengabaikan pilihan lain yang sama pentingnya. Terlepas dari siapa atau dimana informasi tersebut sampai, pembuat keputusan tetap berpegang teguh pada keyakinannya sendiri (Mintz \& DeRouen Jr, 2010). Hal terpenting bagi Trump adalah menemukan dan menghasilkan Informasi yang sesuai dengan citra dan keyakinan sebelumnya tanpa mempertimbangkan kemungkinan alternatif lain.

Sementara itu, pada kepemimpinan Joe Biden kali ini kebijakan luar negeri Amerika Serikat berkisar pada kontinuitas pemberlakuan sanksi ekonomi, keterlibatan diplomatik, dan kerja sama internasional sebagai sarana untuk menghentikan Iran dari ambisi senjata nuklirnya. Dibawah Joe Biden, Amerika Serikat akan memberlakukan banyak sanksi ekonomi atau tekanan secara diplomatik tetapi pada saat yang sama juga akan meringankan sanksinya dan meningkatkan hubungannya dengan Iran (jika Iran memiliki upaya untuk menghentikan pengembangan senjata nuklirnya). Selagi mempertimbangkan alternatif lain untuk mencegah Iran mengembangkan senjata nuklirnya, Biden menyatakan bahwa preferensi yang jelas Amerika Serikat adalah untuk menangani masalah Iran adalah melalui resolusi diplomatik damai (Dewi, 2020). 
Prinsip konstruktivisme yang menyatakan bahwa simbol linguistik (bahasa) memainkan peranan yang sangat penting dalam membentuk impresi hubungan antar aktor, sejalan dengan sikap Trump yang sejak awal kemenangannya menganggap Iran sebagai ' 'lawan'. Hal tersebut terjadi karena kurangnya unsur simbolik, intensitas hubungan, dan intensi yang tidak selaras antar kedua negara tersebut (Hadiwinata, 2017). Sementara pada kepemimpinan Joe Biden, Amerika Serikat akan terus mencoba memperbaiki hal-hal tersebut sehingga isu program nuklir Iran dapat ditangani dengan cara damai, seperti yang dikatakan oleh juru bicara Departemen Luar Negeri AS, Edward Price bahwa Amerika Serikat siap bertemu dengan Iran untuk membicarakan mengenai permasalahan nuklir Iran (DW, 2021).

\subsection{Pengaruh kebijakan luar negeri Amerika Serikat terhadap perekonomian Iran}

Perekonomian Iran jatuh setelah Amerik Serikat menarik diri dari perjanjian JCPoA dan kembali menjatuhkan sanksinya kepada Iran. Joe Biden menyatakan bahwa Amerika Serikat dibawah kepemimpinanya juga akan terus menjatuhkan sanksi terhadap Iran sebagai tanggapan atas upaya Tehran yang membuat Timur Tengah tidak stabil.

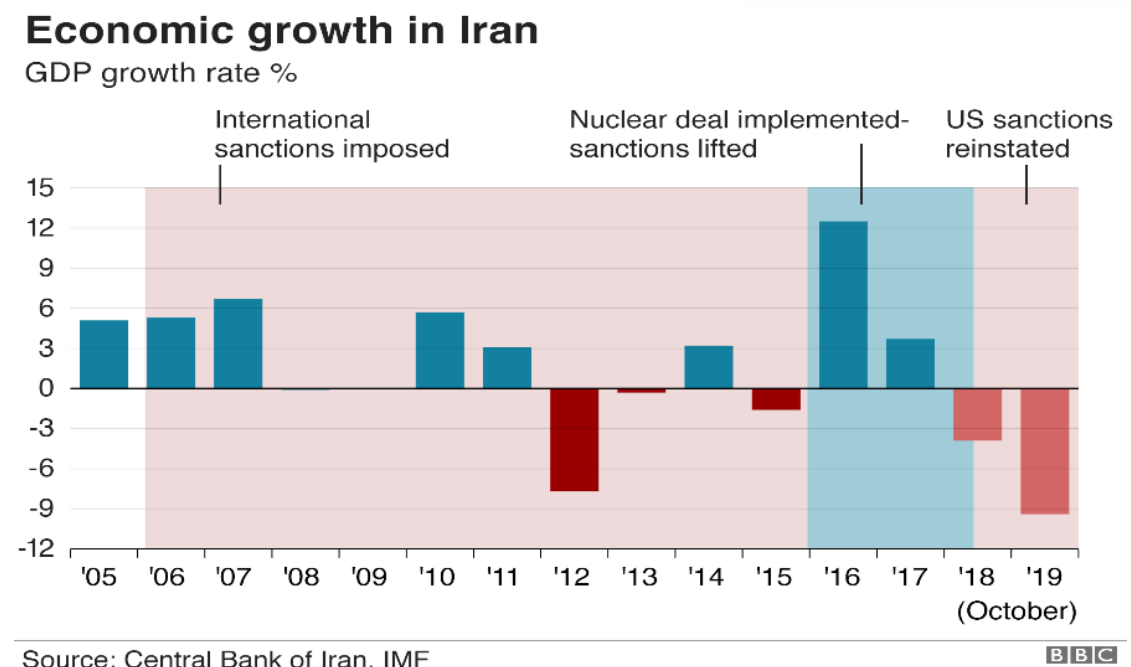

Gambar 2. Pertumbuhan Ekonomi Iran

(Sumber : www.bbc.com)

Berdasarkan diagram diatas dapat dilihat bahwa setelah komitmen Iran berdasarkan pada kesepakatan Joint Comprehensive Plan of Action (JCPOA) diimplementasikan, menurut Bank Sentral Iran terjadi peningkatan pada pertumbuhan ekonomi yang ditandai dengan peningkatan 
PDB mencapai 12,3\%. Tetapi sebagian besar dari pertumbuhan tersebut dikaitkan dengan industri minyak dan gas, dan pemulihan sektor-sektor lain tidak sepenting yang diharapkan kebanyakan orang Iran. Setelah diberlakukan kembali sanksi AS pada 2018 - khususnya yang dikenakan pada sektor energi, perkapalan, dan keuangan pada November - menyebabkan perekonomian Iran kembali memburuk.

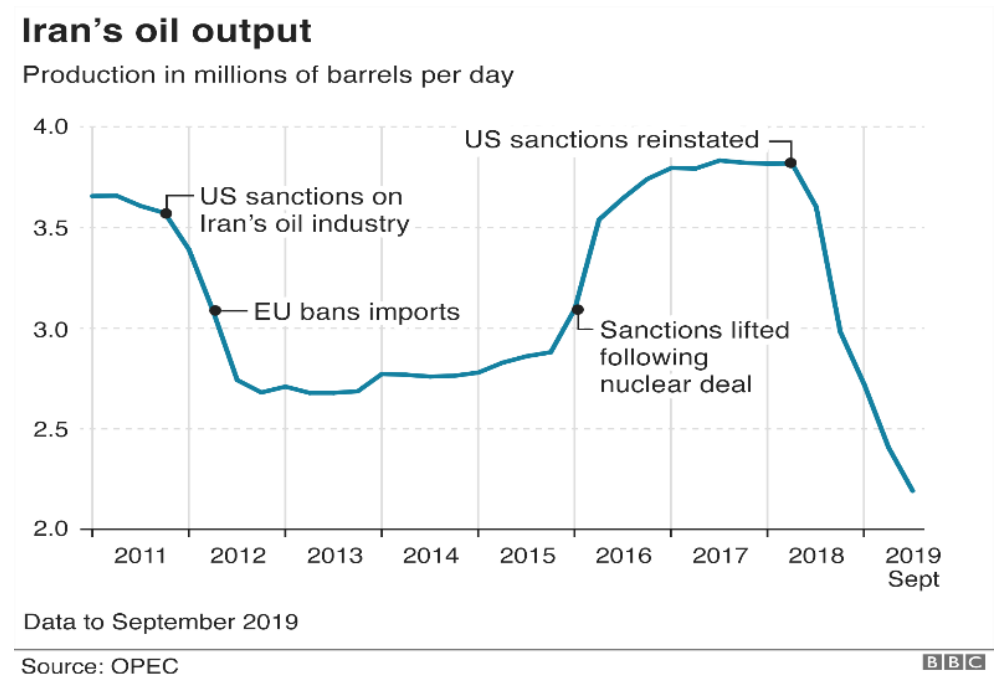

\section{Gambar 3. Produksi Minyak Iran}

(Sumber : www.bbc.com)

Setelah diangkatnya sanksi terhadap Iran yang dijatuhkan oleh berbagai pihak salah satunya Amerika Serikat, membuat produksi minyak mentah Iran meningkat sampai 3,8 juta barel per hari (bph). Namun tak lama dari itu seiring dengan Amerika Serikat yang mengundurkan diri dari JCPOA, Trump memutuskan untuk mengizinkan pengecualian tersebut berakhir dan menyatakan bahwa ia berniat untuk membuat ekspor minyak Iran menjadi nol (export to zero). 


\section{Iran's currency has hit record lows recently}

Number of Iranian rials to one US dollar at unofficial market rate

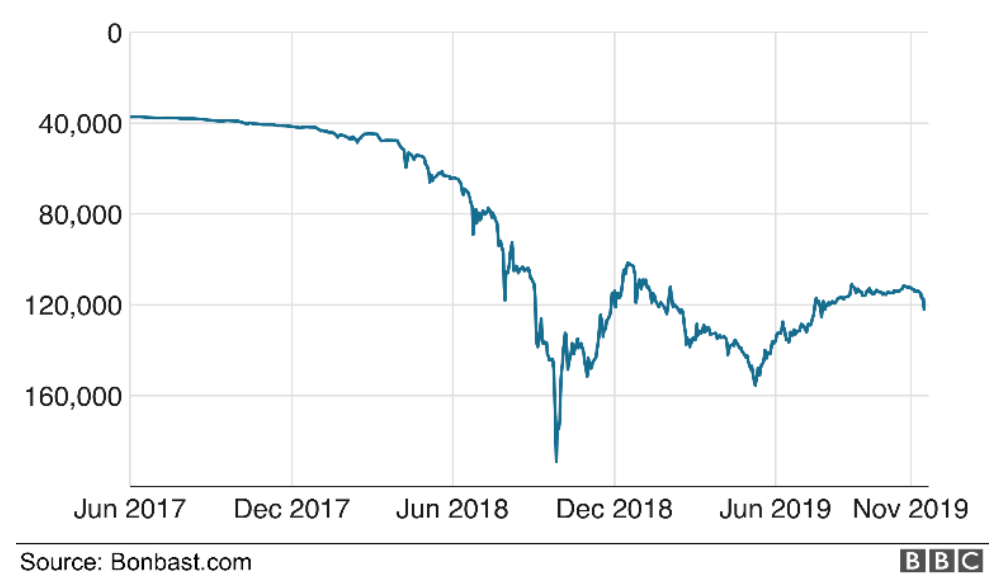

Gambar 4, Penurunan Nilai Tukar Mata Uang Iran

(Sumber : $\underline{w w w . b b c . c o m}$ )

Mata uang Iran telah mencapai rekor terendah baru-baru ini. Melemahnya mata uang Iran ini dikaitkan dengan permasalahan ekonomi yang terjadi setelah Amerika Serikat memberlakukan kembali sanksinya terhadap Iran. Kesengsaraan mata uang Iran menyebabkan meningkatnya inflasi dan kekurangan barang serta produk impor bahan mentah dari luar negeri. (BBC, 2019).

Setelah berbagai permasalahan ekonomi terjadi pada Iran akibat mendurnya Amerika Serikat dari JCPOA dan kembali menjatuhkan sanksi ekonominya, Iran pun merespon dengan meminta bantuan kepada negara-negara Uni Eropa namun permintaan tersebut ditolak dan Uni Eropa menyatakan bahwa mereka akan terus memantau komitmen Iran terhadap JCPOA. Kebijakan baru Joe Biden yang akan mengambil jalan diplomasi dalam menghadapi nuklir Iran, hal tersebut menjadi angin segar bagi perekonomian Iran mengingat keuntungan ekonomi yang mungkin mengalir dalam membantu Iran untuk bangun dari keterpurukannya (Reuters, 2021).

\section{KESIMPULAN}

Perkembangan senjata militer pemusnah massal yang dilakukan Iran telah mendorong Amerika Serikat untuk terus berupaya mengendalikannya. Berbagai kebijakan luar negeri di setiap periode kepemimpinan telah diterapkan Amerika Serikat terhadap Iran, seperti 
pendekatan maksimum seperti yang diterapkan Donald Trump dan dianggap sebagai kebijakan yang irasional karena terlalu memperhatikan apa yang ia yakini dan mengabaikan pilihan lain, serta pendekatan-pendekatan soft diplomacy. Kebijakan luar negeri Joe Biden kali ini sedikit membawa angin segar bagi Iran. Hal tersebut dikarenakan kebijakan baru Joe Biden akan mengambil jalan diplomasi sebagai mekanisme resolusi konflik nuklir Iran, sanksi ekonomi yang akan diterapkan kepada Iran di era Joe Biden pun akan diringankan asalkan Iran mau mematuhi komitmennya dalam Join Comprehensive Plan of Action (JCPOA). Berbeda dengan Trump yang dianggap kurangnya unsur simbolik (komunikasi), intensitas hubungan, dan intensi yang tidak selaras dengan Iran. Biden menyatakan siap untuk bertemu dan melakukan lebih banyak komunikasi antar keduanya agar dapat menangani permasalahan nuklir Iran tersebut dengan damai. Upaya Biden tersebut meningkatkan citra Amerika Serikat di mata dunia dengan kembali menjadi bagian dari kerja sama multilateral global yang ditinggalkan Trump selama pemerintahannya.

\section{DAFTAR PUSTAKA}

[1] Abdillah, M. F. (2019). Kebijakan Amerika Serikat Terhadap Iran Pasca Mundurnya Amerika Serikat dari Joint Comprehensive Plan of Action (JCPOA). Universitas Komputer Indonesia, 1-12.

[2] Azwar, A., \& Suryana, M. J. (2013). Analisis Konstruktivisme tentang Persepsi Ancaman. Jurnal Global \& Strategis, 5-15.

[3] BBC. (2019, July 10). Kesepakatan nuklir Iran: Mengapa batas pengayaan uranium jadi bagian penting? Retrieved October 29, 2021, from BBC: https://www.bbc.com/indonesia/dunia-48936047

[4] BBC. (2019, December 9). Six charts that show how hard US sanctions have hit Iran. Retrieved October 30, 2021, from BBC: https://www.bbc.com/news/world-middle-east48119109

[5] BBC. (2020, November 7). Pemilu Amerika: Bagaimana Joe Biden mengubah kebijakan luar negeri konfrontatif Trump? Retrieved October 29, 2021, from BBC: https://www.bbc.com/indonesia/dunia-54851305

[6] Bogdan, R., \& Taylor, S. (1975). Introduction to Qualitative Research Methods: A Phenomenological Approach to The Social Sciences. New York: A Willey Interscience Publication. 
[7] Dewi, D. S. (2020, November 18). Bagaimana Kebijakan Luar Negeri AS Terhadap Iran Era Joe Biden? Retrieved October 29, 2021, from tirto.id: https://tirto.id/bagaimanakebijakan-luar-negeri-as-terhadap-iran-era-joe-biden-f69L

[8] DW. (2021, February 23). AS dan Iran Hadapi Jalur Terjal Menuju Resolusi Nuklir. Retrieved October 30, 2021, from DW.Com: https://www.dw.com/id/as-dan-iran-hadapijalur-terjal-menuju-resolusi-nuklir/a-56663223

[9] Elster, J. (1989). Nuts and Bolts for the Social Sciences. Cambridge: Cambridge University Press.

[10] Freedman, L. (1976). Logic, Politics and Foreign Policy Processes: A Critique of the Bureaucratic Politics Model. International Affairs, 52(3), 434-449.

[11] Hadiwinata, B. S. (2017). Studi dan Teori Hubungan Internasional : Arus Utama, Alternatif, dan Reflektivis. Jakarta: Yayasan Pustaka Obor Indonesia.

[12] Han, S., \& Jeong, H. (2020). Identifying Joe Biden' China Policy Determinants: Norms \& Values Oriented Diplomacy. Journal of Research Methodology, 5(3), 153-182.

[13] Hunt, J. (2017). Nuclear Arms Control in US Foreign Policy. Oxford Research Encyclopedia of American History, 2-10.

[14] Jemadu, A. (2008). Politik Global dalam Teori \& Praktik. Yogyakarta: Graha Ilmu.

[15] Kartini, I. (2005). Indonesia and Iran Nuclear Issue. LIPI Press , 09-10.

[16] Khan, S. (2010). Iran and Nuclear Weapons: Protracted Conflict and Proliferation. New York: Routledge.

[17] Kibaroglu, M. (2006). Good For the Shah, Banned for the Mullahs: The West and Iran's Quest for Nuclear Power. The Middle East Journal, 202-210.

[18] Krige, J. (2006). Atoms for Peace, Scientific Internationalism, and Scientific Intelligence. Global Power Knowledge: Science and Technology in International Affairs, 21(1), 161181.

[19] Mabee, B. (2011). Historical Institutionalism and Foreign Policy Analysis: The Origins of the National Security Council Revisited. Foreign Policy Analysis, 7(1), 27-44.

[20] Mardalis. (2006). Metode Penelitian : Suatu Pendekatan Proposal. Jakarta: Bumi Aksara.

[21] Mintz, A., \& DeRouen Jr, K. (2010). Understanding Foreign Policy Decision Making. Cambridge: Cambridge University Press.

[22] Morin, J. F., \& Paquin, J. (2018). Foreign Policy Analysis: A Toolbox. Cham: Springer International.

[23] Nainggolan, P. P., \& Muhamad, S. V. (2020). The 2020 Unites States Presidential Election and Its Implications for the World. IINFO Singkat : International Relations Division, 16. 
[24] Onuf, N. G. (1989). World of Our Making: Rules and Rule in Social Theory and International Relations. Columbia: University of South Carolina Press.

[25] Perwita, A. B., \& Yani, Y. M. (2017). Pengantar Ilmu Hubungan Internasional. Bandung: Remaja Rosdakarya.

[26] Ramadhan, R. B. (2019). Pengaruh Peningkatan Kekuatan Iran Terhadap Hegemoni Amerika Serikat di Timur Tengah. Analisis: Jurnal Studi Keislaman, 19(1), 2-10.

[27] Reuters. (2021, October 26). Utusan AS Sebut Upaya Kesepakatan Nuklir dengan Iran Berada pada 'Fase Kritis'. Retrieved October 30, 2021, from voaindonesia.com: https://www.voaindonesia.com/a/utusan-as-sebut-upaya-kesepakatan-nuklir-denganiran-berada-pada-fase-kritis-/6285746.html

[28] Rosenau, J. N. (1969). International Politics and Foreign Policy: A Reader in Research and Theory. New York: The Free Press.

[29] Sinaga, O. (2009). Kepemilikan Nuklir dan Keamanan Nasional Iran: Suatu Studi Kasus. Sosiohumaniora: Journal of Social Sciences and Humanities, 17-34.

[30] Sulaeman, F. H., \& Tiara, N. S. (2021). New Normal in International Relations: Possible Joe Biden's Foreign Policy. Jurnal Kajian Lembaga Ketahanan Nasional Rpublik Indonesia, 9(1), 5-8.

[31] Sundari, R. (2020). Strategi Amerika Serikat Dalam Menekan Pengembangan Nuklir Iran. Frequency of International Relations, 3-4.

[32] Sundari, R. (2020). Strategi Amerika Serikat Dalam Menekan Pengembangan Nuklir Iran. Frequency of International Relations , 1-27.

[33] Waltz, K. (1979). Theory of International Politics. London: Addison-Wesley Publishing Company. 